\title{
THE VEGETABLE ZINGO VUCAVO PESTICIDATION MARKETING STRATEGY
}

\section{STRATEGI PEMASARAN PESTISIDA NABATI ZINGO VUCAVA}

\author{
Nadila Savira ${ }^{\text {1) }}$, Eqy Astanza ${ }^{2)}$, Dian Fiola Sari ${ }^{3)}$ \\ 1) Program Studi Agribisnis, Universitas Muhammadiyah Sumatera Utara Medan, E-mail \\ 2) Program Studi Agribisnis, Universitas Muhammadiyah Sumatera Utara Medan, E-mail \\ 3) Program Studi Agribisnis, Universitas Muhammadiyah Sumatera Utara Medan, E-mail \\ nadilasafirah01@gmail.com, eqiastanza@gmail.com, sdianfiola@gmail.com
}

\begin{abstract}
Soybean plants are the most related food crops, and the demand for soybean production is getting higher, but there are obstacles that occur so that the productivity of soybean plantsdecreases over time. In this activity we use experimental methods. This research was conducted at the Muhammadiyah University of North Sumatra and this activity was in accordance with a schedule that would take 4 months. By producing a product "ZINGO VUCAVA" which helps soybean farmers in eradicating the borer caterpillar pest so that the productivity produced in the future will increase. The product "VUCAVA ZINGO" is a pesticide made from natural ingredients, so it does not have a negative impact on the surrounding environment and health for consumers.
\end{abstract}

Keywords: Soybean, Zingo Vucava, Vegetable Pesticides

\begin{abstract}
Abstrak.
Tanaman kedelai adalah tanaman pangan yang paling terkait kandungan nutrisinya, dan permintaan terhadap produksi kedelai ini semakin tinggi, tetapi terdapat hambatan yang terjadi sehingga produktivitas dari tanaman kedelai semakin lama semakin menurun. Dalam kegiatan ini kami menggunakan metode eksperimental. Penelitian ini dilakukan di Universitas Muhammadiyah Sumatera Utara dan kegiatan ini sesuai dengan jadwal yang akan memakan waktu 4 bulan lamanya. Dengan menghasilkan sebuah produk "ZINGO VUCAVA" yang membantu para petani kedelai dalam membasmi hama ulat penggereknya sehingga produktivitas yang dihasilkan kedepannya lebih meningkat. Produk "ZINGO VUCAVA" merupakan pestisida yang terbuat dari bahan alami, sehingga tidak membawa dampak yang buruk terhadap lingkungan sekitar dan kesehatan bagi para konsumen kedelai.
\end{abstract}

Kata kunci: Kedelai, Zingo Vucava, Pestisida Nabati

\section{A. PENDAHULUAN}

Kedelai (Glycine max L.) adalah salah satu komoditas utama kacang-kacangan yang menjadi andalan nasional karena merupakan sumber protein nabati penting untuk diversifikasi pangan dalam mendukung ketahanan pangan nasional. Kedelai merupakan tanaman legum yang kaya protein nabati, karbohidrat dan lemak. Biji kedelai juga mengandung fosfor, besi, kalsium, vitamin B dengan komposisi asam amino lengkap, sehingga potensial untuk pertumbuhan tubuh manusia. Kedelai juga mengandung asam-asam tak jenuh yang dapat mencegah timbulnya arteri sclerosis yaitu terjadinya pengerasan pembuluh nadi (Khotbawan I. dkk, 2015).

Kebutuhan akan kedelai terus meningkat dari tahun ke tahun linear dengan peningkatan jumlah penduduk, sementara produksi yang dicapai belum mampu mengimbangi kebutuhan tersebut. Pada tahun 2004 misalnya, kebutuhan kedelai di Indonesia diperkirakan mencapai 1.951.100 ton sedangkan produksi pada tahun yang sama hanya 672.439 ton yang menunjukkan defisit 1.278 .661 ton $(34,46 \%)$. Untuk memenuhi jumlah kekurangan ini dan mempertahankan tingkat konsumsi yang cukup pada masa mendatang, hasil tanaman kedelai harus terus ditingkatkan. (Afiyanti E. dan Triono B, 2016).

Hama utama pada tanaman kedelai dikelompokkan menjadi hama perusak bibit, perusak daun, dan perusak polong. Hama perusak polong terdiri dari hama pengisap dan penggerek polong. Ada tiga spesies hama penghisap polong di Indonesia yang sering menyerang pertanaman kedelai yaitu R. linearis F., Nezara viridula L. dan Piezodorus hybneri . Diantara ketiga jenis hama tersebut R. linearis mempunyai daerah penyebaran dan serangan yang paling luas. Sedangkan penggerek polong 
yaitu Etiella zinckenella Treischke dan E. hobsoni Butler. Spesies yang dominan dan memiliki daerah penyebaran yang paling luas adalah Etiella zinckenella Treischke. Hama polong kedelai sangat merugikan, karena secara langsung merusak biji, menurunkan produksi dan kualitas biji yang selanjutnya berpengaruh langsung pada kebugaran benih. Kehilangan hasil akibat serangan hama polong penghisap dan penggerek polong kedelai dapat mencapai hingga 80\% (Siburian D. dkk, 2013).

Dalam upaya untuk mengendalikan hama, petani sekarang masih bertumpu pada insektisida, karena cara-cara yang lain seperti penggunaan varietas tahan dan musuh alami belum banyak digunakan. Pengendalian hama menggunakan insektisida sudah biasa di lakukan, tetapi kegagalan dalam menanggulangi hama masih sering terjadi. Penggunaan insektisida tanpa didasari pengetahuan bioekologi hama dan teknik aplikasi yang benar mengakibatkan tidak tercapainya tujuan pengendalian, bahkan dapat menyebabkan terjadinya kasus resistensi dan resurjensi (Radiyanto. Dkk,2010).

Penggunaan pestisida yang tidak tepat dapat membahayakan kesehatan petani dan konsumen, mikroorganisme non target serta berdampak pada pencemaran lingkungan baik itu tanah dan air. Pencemaran akibat penggunaan pestisida telah dibuktikan dengan beberapa penelitian, antara lain: pencemaran air dan tanah akibat penggunaan pupuk dan pestisida. ( $\mathrm{G}$. Maria C. Y. dkk, 2015).

Alternatif lain pengendalian yakni dengan penggunaan insektisida nabati. Penggunaan insektisida nabati ini ramah lingkungan dan aman bagi manusia dan ternak dikarenakan berbahan dasar alami sehingga mudah terurai di alam, namun penggunaan insektisida nabati di Indonesia masih relatif sedikit, hal ini dapat dilihat dari merek insektisida nabati/hayati yang beredar, yakni sekitar 22 (Hoesain. dkk, 2018).

Pestisida Nabati (pesnab) adalah pestisida yang bahan dasarnya berasal dari tumbuhan. Penggunaan pesnab selain dapat mengurangi pencemaran lingkungan, harganya relatif lebih murah apabila dibandingkan dengan pestisida kimia. Banyak jenis tumbuhan yang dapat digunakan sebagai pestisida nabati. (Yogi A. dan Oktarina, 2017).

Berdasarkan uraian diatas maka kami menciptakan suatu inovasi baru yang dapat membantu para petani untuk mengendalikan hama ulat penggerek (Etilia zincknella) yaitu Inovasi baru yang dapat menggantikan peran insektisida kimia dan beralih ke insektisida nabati yang diberi nama "Zingo vucava" yang kehadirannya membantu para petani untuk mengendalikan hama ulat penggerek sehingga mampu mempertahankan hasil panen petani.

Dalam kewirausahaan yang kami usulkan ini mempunyai tujuan, yaitu dapat membantu para petani kedelai dalam mengendalikan hama ulat penggerek dengan pestisida nabati Zingo vucava. Pestisida nabati yang kami olah untuk membantu para petani dalam mengendalikan hama ulat penggerek secara efektif dan efisien. Kami juga memasarkan zingo vucava dengan harga yang terjangkau sesuai dengan kondisi dikalangan petani. Karena biasa nya petani memikirkan biaya yang harus mereka keluarkan dalam mengolah suatu tanaman. Dengan adanya usaha kami ini yang memiliki harga yang terjangkau juga untuk memudahkan para petani sehingga petani mengeluarkan biaya yang sedikit tetapi mendapatkan hasil yang maksimal..

\section{B. METODE PENELITIAN}

Penelitian ini metode yang digunakan adalah melakukan persiapan bahan, pembuatan produk dan melakukan pemasaran. Kegiatan ini dilaksanan sesuai jadwal yang ada dan diperlukan waktu selama 4 bulan.

Adapun bahan yang digunakan dalam penelitian ini adalah cabai hijau (Capsicum annum var annum), bawang putih (Allium sativum), dan jahe (Zingiber officinale), sarung tangan, dan masker. Sementara itu, alat yang digunakan dalam praktikum ini adalah kompor, panci, pisau, saringan,

pengaduk, blender, baskom, corong, dan telenan.

\section{HASIL dan PEMBAHASAN}

Tahapan pelaksanaan pembuatan produk dapat dilihat pada diagram dibawah ini :

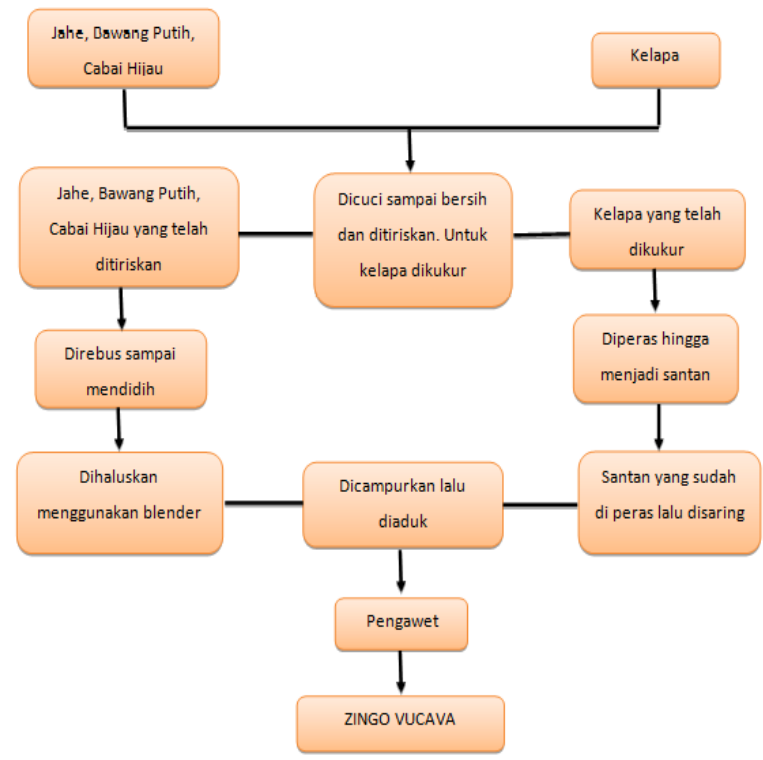




\section{THE VEGETABLE ZINGO VUCAVO PESTICIDATION}

Selanjutnya pencapaian tujuan program bersangkutan dengan proses penjualan zingo vucava yang meliputi:

\section{Pengemasan.}

Setelah Produk zingo vucava dihasilkan, perlu penanganan agar produk terjual di pasaran, seperti pengemasan. Kemasan merupakan salah satu sumber daya tarik bagi konsumen untuk membeli produk. Zingo vucava dikemas dalam botol yang dirancang khusus.

2. Pemasaran.

Perencanaan pemasaran yang akan dilakukan dalam mengenalkan produk dilakukan melalui metode iklan dan promosi penjualan. Bentuk iklan yang direncanakan adalah dengan cara menyebarkan brosur dan secara online. Setelah proses pemasaran selesai, tim pelaksana akan melakukan evaluasi usaha untuk melihat perkembangan pencapaiaan tujuan program yang dilaksanakan, untuk mengetahui kendala yang ada, cara menanganinya, mengontrol dan menganalisa sehingga program yang dilakukan benarbenar efektif dan maksimal

Dalam 4 bulan peneliti memproduksi zingo vucava yang menggunakan bahan baku Cabai Hijau sebanyak $15 \mathrm{~kg}$, Bawang Putih sebanyak $15 \mathrm{~kg}$ dan Jahe $15 \mathrm{~kg}$ untuk menghasilkan zingo vucava ukuran $300 \mathrm{ml}$ sekitar 300 Botol.

Harga untuk 1 botol adalah 28.500 sehingga akan diperoleh pendapatan kotor di setiap minggunya adalah sebesar 300 botol $\mathrm{x}$ 28.500,- = Rp. 8.550.000,

Adapun keseluruhan modal yang akan dikeluarkan di awal pendirian usaha, meliputi peralatan, bahan habis pakai, transportasi, promosi, dan lain-lain adalah Rp. 7.255.000,- ( Jadi, jika dihitung berdasarkan keseluruhan modal awal yang meliputi bahan habis pakai, peralatan, dan biaya lain-lain sebesar $\mathrm{Rp}$. 7.255.000,- maka modal akan kembali dalam waktu 2 minggu.

Analisis break event point (BEP) menunjukkan data sebagai berikut:

$$
\begin{aligned}
\mathrm{BEP}(\text { unit })= & \mathrm{FC} /(\mathrm{P}-\mathrm{VC}) \\
& =456.000 /(28.500-22.600) \\
& =77 \text { unit } \\
\mathrm{BEP}(\text { rupiah }) & =\mathrm{FC} /(1-\mathrm{VC} / \mathrm{P}) \\
& =\text { Rp.2.280.000,- }
\end{aligned}
$$

Berdasarkan BEP di atas maka BEP akan terpenuhi dalam waktu 1 minggu dan untuk produksi selanjutnya maka sudah mendapatkan keuntungan.

Dalam 1 bulan dapat menghasilkan 600 botol, dengan demikian dapat dihitung keuntungan yang diperoleh:

Keuntungan:

$\pi=\mathrm{TR}-\mathrm{TC}$

$=17.100 .000-7.255 .000$

$=$ Rp. 9.845.000,- $/$ bulan

\section{KESIMPULAN}

Kedelai merupakan salah satu komoditas pangan utama setelah padi yang mempunyai nilai ekonomi yang cukup tinggi, yaitu sebagai sumber protein nabati bagi kebutuhan pangan manusia, namun dapat juga dijadikan sebagai pakan ternak dan bahan baku obat-obatan lainnya.

Adapun kesimpulan ini ialah :

1 Dapat mengendalikan hama ulat penggerek,

2 Produktivitas tanaman kedelai akan meningkat,

3 Ramah lingkungan,

4 Harga terjamgkau dikalangan petani.

\section{REFERENSI}

Afriyanti E. R., Triono B. S. (2016). Analisis pertumbuhan tanaman kedelai (Glycine max L.) varietas grobogan pada kondisi cekaman genangan. Jurnal Sains dan Seni. 5(2):2337-3520.

Astanza E., Agus S., Muhammad P. (2018). BIO-RECHIPE GARCO Pestisida Nabati pencegah hama thrips pada tanaman cabai (capsicum annum L.). Jurnal Sains Penelitian dan Pengabdian. 1(1):13-20.

G. Maria C. Y., Budi W., Henna R. S. (2015). Analisis resiko pajanan pestisida terhadap kesehatan petani. Jurnal kesehatan masyarakat. 10(2):239-245.

Hasnah dan Ilyas A. (2007). Efektivitas ekstrak umbi bawang putih (Allium sativum L.) untuk mengendalikan hama Crocidolomia pavonana F. Pada tanaman sawi. Agrista. 11(2).

Hersanti, Santosa E., Dono D. (2013). Pelatihan pembuatan pestisida alami untuk mengendalikan hama dan penyakit tanaman padi di desa tenjolaya dan desa sukamelang kecamatan kasomalang kabupaten subang. 
Jurnal Aplikasi Ipteks untuk Masyarakat. 2(2):139-145.

Hoesain M., Sigit P., Rinanda A. (2018).Uji efektivitas estrak daun sirsak sebagai insektisida nabati terhadap mortalitas kutu daun (Aphis glycines Matsumura) pada tanaman kedelai. (Seminar Nasional). Jember:Universitas Jember.

Khotbawan I., Heniyati H., R. Iin S.A. (2015). Pengaruh jarak tanam dan pemberian pupuk hayati terhadap pertumbuhan dan produksi tanaman kedelai (Glycine max L. Merrill) dan jagung (Zea mays L.) dengan pola tanam tumpang sari di lahan lebak. Klorofil. X(2):76-81.

Radiyanto I., Mochammad S., Noeng M. N. (2010). Keanekaragaman serangga hama dan musuh alami pada lahan pertanaman kedelai di kecamatan Balong-Ponorogo. J. Entomol Indon. 7(2):116-121.
Sarawa, Andi N., Muh D. (2012). Pertumbuhan dan produksi tanaman kedelai (Glycine max L.) yang diberi pupuk guano dan mulsa alang-alang. Jurnal agroteknos. 2(2):97105.

Siburian D., Yuswani P., Lahmuddin L. (2013). Pengaruh jenis insektisida terhadap hama polong Riptortus linearis F. (Hemiptera:Alydidae) dan Etiella zinckenella Treit. (Lepidoptera:Pyralidae) pada tanaman kedelai (Glycine max L.). Jurnal Online Agroekoteknologi. 2(2):893904.

Yogi A. M., Oktarina. (2017). Respon kedelai edamame (Glycine max, L. Merrill) terhadap waktu aplikasi dan konsentrasi pestisida nabati gadung. Agritrop. 15(1):445. 
